\title{
Triterpenes and Triterpenoidal Glycosides from the Fruits of Ilex paraguariensis (Maté)
}

\author{
Alexandre T. C. Taketa ${ }^{a}$, Eberhard Breitmaier ${ }^{a}$ and Eloir P. Schenkel ${ }^{*, b}$ \\ ${ }^{a}$ Kekulé-Institut für Organische Chemie und Biochemie der Rheinischen Friedrich-Wilhelms-Universität, Bonn. \\ Gerhard Domagk Straße 1, 53121 Bonn, Germany \\ ${ }^{b}$ Departamento de Ciências Farmacêuticas., Centro de Ciências da Saúde, Universidade Federal de Santa Catarina, \\ 88.040-900 Florianópolis - SC, Brazil
}

\begin{abstract}
Dos frutos de Ilex paraguariensis foram isolados um novo glicosídeo triterpenóide, o ácido rotúndico $3 \beta$-O- $\alpha$-L-arabinopiranosídeo, denominado matesídeo (4), os triterpenos ácido ursólico (1), ácido acetilursólico (2), ácido 23-hidroxi-ursólico (3) e as saponinas ziyu-glicosídeo I (5) e ilexosídeo II (6). As estruturas foram estabelecidas com base em métodos espectroscópicos, principalmente RMN mono- e bidimensional. Os valores de amargor foram determinados para matesídeo e ilexosídeo II e comparados com os valores obtidos para as saponinas de I. paraguariensis e outras espécies de Ilex. O elevado amargor encontrado para o ilexosídeo II, uma das saponinas majoritárias presentes nos frutos e não encontrada nas folhas de I. paraguariensis, sugere que o uso dos frutos alteraria de maneira significativa o sabor do produto erva-mate e também poderia produzir efeitos fisiológicos ainda não conhecidos.
\end{abstract}

A new triterpenoid glycoside, $3 \beta$-O- $\alpha$-L-arabinopyranosyl rotundic acid, named here mateside (4), and the known triterpenes ursolic acid (1), acetylursolic acid (2), 23-hydroxyursolic acid (3), the saponins ziyu-glycoside I (5) and ilexoside II (6), were isolated from fruits of Ilex paraguariensis. Their structures were established on the basis of 1D and 2D NMR spectroscopic methods. The threshold bitterness values for mateside and ilexoside II were also determined and compared with saponins obtained from leaves of I. paraguariensis and other Ilex species. The high bitterness of Ilexoside II, one of the main saponins found the fruits, but not in the leaves of I. paraguariensis, suggests that the utilization of the fruits in the Maté production can produce a strong taste variation and unknown physiological effects.

Keywords:Ilex, saponins, sapogenins, bitterness value, mateside, ilexoside II

\section{Introduction}

Leaves and twigs of Ilex paraguariensis St. Hil. (Aquifoliaceae) are historically used in Brazil, Argentina, Paraguay and Uruguay to produce the raw material called "erva-mate". One of the most important and traditional forms of its preparation is the beverage "chimarrão", prepared by infusion of the processed leaves and twigs. The common exportation form consists of the toasted and green dried leaves to prepare the Maté tees, which are well known for their fine bitter taste. The world production of Maté approaches $c a$. 1,000,000 ton per year ${ }^{1}$ and plays a significant cultural, social and economic role in South America. Previously, we described the structure of 11 saponins isolated from the leaves of I. paraguariensis and

\footnotetext{
* e-mail: schenkel@ccs.ufsc.br
}

established that all saponins were glycosides derived from the ursolic and oleanolic acids ${ }^{2}$ and more recently two other minor saponins were described. ${ }^{3}$ We investigated also the structures of the saponins of other Ilex species reported as adulterant of genuine Maté. ${ }^{4}$ The present work deals with the structural elucidation of triterpenes and triterpenoidal glycosides isolated from fruits of $I$. paraguariensis, compounds 1-6. Furthermore, the new compound 4 and the prominent compound $\mathbf{6}$ were evaluated concerning bitterness and compared with the saponins isolated from leaves of I. paraguariensis and other Ilex species.

\section{Results and Discussion}

The hydroethanolic extract of the ripe fruits afforded a complex mixture of triterpenes and triterpenoid glycosides which were isolated by solvent partition and 


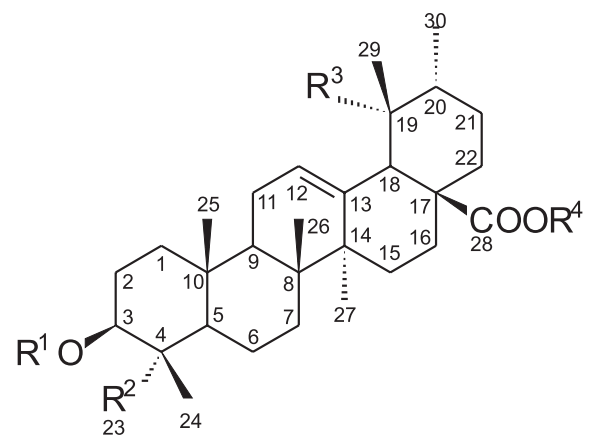

$\begin{array}{lllll} & \mathrm{R} 1 & \mathrm{R}^{2} & \mathrm{R}^{3} & \mathrm{R}^{4} \\ \mathbf{1} & \mathrm{H} & \mathrm{CH}_{3} & \mathrm{H} & \mathrm{H} \\ \mathbf{2} & \mathrm{Ac} & \mathrm{CH}_{3} & \mathrm{H} & \mathrm{H} \\ \mathbf{3} & \mathrm{H} & \mathrm{CH}_{2} \mathrm{OH} & \mathrm{H} & \mathrm{H} \\ \mathbf{4} & \alpha-\mathrm{L}-\mathrm{Ara} 1 \rightarrow & \mathrm{CH}_{2} \mathrm{OH} & \mathrm{HO} & \mathrm{H} \\ \mathbf{5} & \alpha-\mathrm{L}-\mathrm{Ara} 1 \rightarrow & \mathrm{CH}_{3} & \mathrm{HO} & \beta-\mathrm{D}-\mathrm{Glc} 1 \rightarrow \\ \mathbf{6} & \beta-\mathrm{D}-\mathrm{Gl} 1 \rightarrow 3 \alpha-\mathrm{L}-\mathrm{Ara} 1 \rightarrow & \mathrm{CH}_{3} & \mathrm{HO} & \beta-\mathrm{D}-\mathrm{Gl} 1 \rightarrow\end{array}$

chromatographic procedures to give ursolic acid (1), acetylursolic acid (2), 23-hydroxyursolic acid (3), 3 $\beta-O-$ $\alpha$-L-arabinopyranosyl rotundic acid, named mateside (4), ziyu-glycoside I (5) and ilexoside II (6).

Compound 1 was characterized as ursolic acid ${ }^{5,6}$ and compound 2 turned out to be acetylursolic acid. ${ }^{5,7}$ The 2D NMR experiments $\mathrm{H}^{1}-\mathrm{H}^{1} \mathrm{COSY}, \mathrm{HMQC}$ and HMBC brought detailed information allowing to complete the signal assignments reported in the literature (Tables 1 and 2).

The most important NMR feature of compound $\mathbf{3}$ is the presence of a hydroxymethylene group $(\delta 68.0 / \delta 3.71$, $1 \mathrm{H}, d, J 9.9 \mathrm{~Hz}$ and $\delta 4.18,1 \mathrm{H}, d, J 10.3 \mathrm{~Hz}$ ). It was identified as 23-hydroxyursolic acid, which was already found in the root wood of Guettarda angelica, ${ }^{8}$ in the cultured cells from Eucalyptus perriniana ${ }^{9}$ and also described after hydrolysis of the saponins obtained from the leaves of Ilex integra. ${ }^{10}$

Compound 4 exhibited a pseudomolecular ion [M+ $\mathrm{Na}]^{+}$at $m / z, 643$ in the FABMS, which suggested the molecular formula $\mathrm{C}_{35} \mathrm{H}_{56} \mathrm{O}_{9}$. The DEPT subspectra of the ${ }^{13} \mathrm{C}$ experiments revealed the presence of six methyl, eleven methylene and ten methyne carbons. The most relevant features were the presence of one carboxylic acid group $(\delta 181.0)$, one double bound $(\delta 140.2$ and 128.1), one glycosylated sec alcohol group ( $\delta$ 82.1), one tert alcohol group ( $d 72.8)$, two hydroxymethylene groups ( $\delta 67.2$ and $\delta$ 64.6), one anomeric sugar carbon $(\delta$ 106.9) and sugar carbon signals $(\delta 73.3-69.8)$. The signal at $\delta 3.04(\mathrm{H}-18$, $s)$ indicated the presence of a hydroxyl function attached to the carbon 19. Its $\alpha$-configuration was deduced from the $\gamma$-effect between this axial hydroxyl group and C-21
Table 1. ${ }^{13} \mathrm{C}$ NMR data for compounds $1,2, \mathbf{3}, 4,5,6$ (pyridine- $\mathrm{d}_{5}$ )

\begin{tabular}{|c|c|c|c|c|c|c|}
\hline $\mathrm{C}$ & 1 & 2 & 3 & 4 & 5 & 6 \\
\hline 1 & 39.2 & 38.4 & 39.1 & 39.0 & 39.0 & 39.0 \\
\hline 2 & 28.3 & 24.1 & 27.9 & 26.3 & 26.9 & 26.9 \\
\hline 3 & 78.3 & 80.9 & 73.5 & 82.1 & 88.9 & 88.9 \\
\hline 4 & 39.5 & 38.0 & 43.1 & 43.7 & 39.7 & 39.8 \\
\hline 5 & 56.0 & 55.7 & 48.7 & 47.7 & 56.1 & 56.0 \\
\hline 6 & 18.9 & 18.6 & 18.7 & 18.5 & 18.8 & 18.8 \\
\hline 7 & 33.7 & 33.5 & 33.4 & 33.3 & 33.6 & 33.6 \\
\hline 8 & 40.1 & 40.0 & 40.1 & 40.5 & 40.7 & 40.7 \\
\hline 9 & 48.2 & 47.9 & 48.2 & 48.0 & 47.9 & 47.8 \\
\hline 10 & 37.4 & 37.2 & 37.3 & 37.1 & 37.2 & 37.1 \\
\hline 11 & 23.8 & 23.7 & 23.8 & 24.2 & 24.2 & 24.2 \\
\hline 12 & 125.8 & 125.6 & 125.8 & 128.1 & 128.6 & 128.5 \\
\hline 13 & 139.4 & 139.4 & 139.5 & 140.2 & 139.4 & 139.4 \\
\hline 14 & 42.7 & 42.6 & 42.7 & 42.3 & 42.2 & 42.2 \\
\hline 15 & 28.8 & 28.8 & 28.9 & 29.5 & 29.4 & 29.4 \\
\hline 16 & 25.1 & 25.0 & 25.1 & 26.6 & 26.3 & 26.2 \\
\hline 17 & 48.2 & 48.2 & 48.2 & 48.5 & 48.8 & 48.7 \\
\hline 18 & 53.7 & 53.6 & 53.7 & 54.8 & 54.6 & 54.5 \\
\hline 19 & 39.6 & 39.5 & 39.6 & 72.8 & 72.8 & 72.7 \\
\hline 20 & 39.6 & 39.6 & 39.6 & 42.5 & 42.3 & 42.3 \\
\hline 21 & 31.2 & 31.2 & 31.2 & 27.1 & 26.9 & 26.8 \\
\hline 22 & 37.6 & 37.6 & 37.6 & 38.7 & 37.9 & 37.9 \\
\hline 23 & 29.0 & 28.3 & 68.0 & 64.6 & 28.4 & 28.3 \\
\hline 24 & 16.8 & 17.1 & 13.3 & 13.7 & 17.1 & 17.1 \\
\hline 25 & 15.8 & 15.7 & 16.3 & 16.3 & 15.8 & 15.8 \\
\hline 26 & 17.6 & 17.5 & 17.7 & 17.4 & 17.6 & 17.5 \\
\hline 27 & 24.1 & 24.1 & 24.1 & 24.8 & 24.7 & 24.7 \\
\hline 28 & 180.1 & 180.1 & 180.2 & 181.0 & 177.1 & 177.1 \\
\hline 29 & 17.7 & 17.7 & 17.7 & 27.3 & 27.2 & 27.2 \\
\hline 30 & 21.6 & 21.6 & 21.6 & 17.0 & 16.9 & 16.9 \\
\hline $\mathrm{H}_{3} \underline{\mathrm{CCOO}}$ & & 21.3 & & & & \\
\hline $\mathrm{H}_{3}^{3-\mathrm{C}} \mathrm{COO}$ & & 170.7 & & & & \\
\hline Ara-1' & & & & 106.9 & 107.8 & 107.6 \\
\hline Ara-2' & & & & 73.3 & 73.1 & 72.0 \\
\hline Ara-3, & & & & 74.9 & 74.8 & 84.2 \\
\hline Ara-4, & & & & 69.8 & 69.8 & 69.5 \\
\hline Ara-5' & & & & 67.2 & 67.0 & 67.2 \\
\hline Glc-1' & & & & & & 106.6 \\
\hline Glc-2' & & & & & & 75.9 \\
\hline Glc-3' & & & & & & 78.5 \\
\hline Glc-4' & & & & & & 71.6 \\
\hline Glc-5, & & & & & & 78.8 \\
\hline Glc-6' & & & & & & 62.8 \\
\hline Glc-1" & & & & & 96.0 & 95.9 \\
\hline Glc-2" & & & & & 74.2 & 74.2 \\
\hline Glc-3" & & & & & 79.1 & 79.1 \\
\hline Glc-4" & & & & & 71.3 & 71.3 \\
\hline Glc-5" & & & & & 79.5 & 79.4 \\
\hline Glc-6" & & & & & 62.4 & 62.4 \\
\hline
\end{tabular}

( $\delta$ 27.1), that was shielded by about $4 \mathrm{ppm}$ in comparison to the corresponding carbon in $\mathbf{1}, \mathbf{2}$ or $\mathbf{3}(\delta 31.2)$. The signal of the anomeric proton at $\delta 4.98(d, 7.3 \mathrm{~Hz})$ was assigned to L-arabinopyranose with $\alpha$-configuration. Its linkage to the aglycone was supported by the HMBC correlation between C-3 $(\delta$ 82.1) and the anomeric proton Ara-H-1 $(\delta 4.98)$. Furthermore, the signal of C-28 at $\delta 181.0$ 
Table 2. ${ }^{1} \mathrm{H}$ NMR data for compounds $1,2,3,4,5$ and 6 (pyridine- $\mathrm{d}_{5}$ )

\begin{tabular}{|c|c|c|c|c|c|c|}
\hline $\mathrm{H}$ & 1 & 2 & 3 & 4 & 5 & 6 \\
\hline \multirow[t]{2}{*}{1} & $0.96 / \alpha$ & $0.86 / \alpha$ & $1.06 / \alpha$ & $1.04 / \alpha$ & $0.92 / \alpha$ & $0.90 / \alpha$ \\
\hline & $1.54 / \beta$ & $1.44 / \beta$ & $1.58 / \beta$ & $1.58 / \beta$ & $1.53 / \beta$ & $1.52 / \beta$ \\
\hline \multirow[t]{2}{*}{2} & $1.83(2 \mathrm{H})$ & $1.67(2 \mathrm{H})$ & $1.90(2 \mathrm{H})$ & $1.98 / \beta$ & $1.89 / \beta$ & $1.86 / \beta$ \\
\hline & & & & $2.25 / \alpha$ & $2.18 / \alpha$ & $2.12 / \alpha$ \\
\hline \multirow[t]{2}{*}{3} & 3.45 & 4.47 & $4.16^{\mathrm{a}}$ & $4.27^{\mathrm{a}}$ & 3.31 & 3.32 \\
\hline & $(d d ; 10.0,5.8) / \alpha$ & $(d d ; 11.3,4.3) / \alpha$ & & & $(d d ; 11.9,4.3) / \alpha$ & $(d d ; 11.3,3.4) / \alpha$ \\
\hline 5 & $0.85 / \alpha$ & $0.81 / \alpha$ & $1.52 / \alpha$ & $1.71 / \alpha$ & $0.81 / \alpha$ & $0.81 /($ br $d ; 11.3) \alpha$ \\
\hline \multirow[t]{2}{*}{6} & $1.35 / \beta$ & $1.26 / \beta$ & $1.40 / \beta$ & $1.35^{\mathrm{a}}$ & $1.29 / \beta$ & $1.28 / \beta$ \\
\hline & $1.56 / \alpha$ & $1.45 / \alpha$ & $1.62 / \alpha$ & $1.70^{\mathrm{a}}$ & $1.44 / \alpha$ & $1.45 / \alpha$ \\
\hline \multirow[t]{2}{*}{7} & $1.36^{\mathrm{a}}$ & $1.30^{\mathrm{a}}$ & $1.33^{\mathrm{a}}$ & $1.33^{\mathrm{a}}$ & $1.44 / \beta$ & $1.45 / \beta$ \\
\hline & $1.55^{\mathrm{a}}$ & $1.48^{\mathrm{a}}$ & $1.66^{\mathrm{a}}$ & $1.71^{\mathrm{a}}$ & $1.58 / \alpha$ & $1.59 / \alpha$ \\
\hline 9 & $1.62 / \alpha$ & $1.55 / \alpha$ & $1.72 / \alpha$ & $1.93 / \alpha$ & $1.77 / \alpha$ & $1.77 / \alpha$ \\
\hline \multirow[t]{2}{*}{11} & $1.90^{\mathrm{a}}$ & $1.86(2 \mathrm{H})$ & $1.94(2 \mathrm{H})$ & $2.04(2 \mathrm{H})$ & $2.02(2 \mathrm{H})$ & $2.00(2 \mathrm{H})$ \\
\hline & $1.95^{\mathrm{a}}$ & & & & & \\
\hline 12 & 5.48 & 5.46 & 5.48 & 5.57 & 5.55 & 5.53 \\
\hline \multirow[t]{2}{*}{15} & $1.20 / \alpha$ & $1.18 / \alpha$ & $1.15 / \alpha$ & $1.21 / \alpha$ & $1.24 / \alpha$ & $1.23 / \alpha$ \\
\hline & $2.32(t d ; 13.2,4.1) / \beta$ & $2.29(t d ; 13.1,3.7) / \beta$ & $2.30(t d ; 13.4,4.5) / \beta$ & $2.30(t d ; 13.2,3.9) / \beta$ & $2.48(t d ; 13.6,3.7) / \beta$ & $2.47(t d ; 11.4,2.9) / \beta$ \\
\hline \multirow[t]{2}{*}{16} & $2.00 / \beta$ & $1.99 / \beta$ & $1.96 / \beta$ & $2.02 / \beta$ & $2.02 / \beta$ & $2.02 / \beta$ \\
\hline & $2.11(t d ; 13.3,3.9) / \alpha$ & $2.10(t d ; 14.0,4.3) / \alpha$ & $2.07(t d ; 13.6,3.9) / \alpha$ & $3.08(t d ; 13.2,3.9) / \alpha$ & $3.11(t d ; 12.9,4.6) / \alpha$ & $3.11(t d ; 12.3,3.5) / \alpha$ \\
\hline 18 & $2.63(d ; 11.3) / \beta$ & $2.62(d ; 11.3) / \beta$ & $2.62(d ; 11.5) / \beta$ & $3.04(s) / \beta$ & $2.93(s) / \beta$ & $2.99(s) / \beta$ \\
\hline 19 & $1.46 / \alpha$ & $1.47 / \alpha$ & $1.52 / \alpha$ & -- & -- & -- \\
\hline 20 & $0.99 / \beta$ & $0.98 / \beta$ & $0.95 / \beta$ & $1.48 / \beta$ & $1.34 / \beta$ & $1.35 / \beta$ \\
\hline \multirow[t]{2}{*}{21} & $1.36 / \alpha$ & $1.31 / \alpha$ & $1.36^{\mathrm{a}}$ & $2.08(2 \mathrm{H})$ & $1.21 / \beta$ & $1.21 / \beta$ \\
\hline & $1.45 / \beta$ & $1.48 / \beta$ & $1.43^{\mathrm{a}}$ & & $1.98 / \alpha$ & $1.99 / \alpha$ \\
\hline \multirow[t]{2}{*}{22} & $1.97(2 \mathrm{H})$ & $1.94(2 \mathrm{H})$ & $1.94(2 \mathrm{H})$ & $2.03^{\mathrm{a}}$ & $1.84 / \beta$ & $1.84 / \beta$ \\
\hline & & & & $2.13^{\mathrm{a}}$ & $2.06 / \alpha$ & $2.04 / \alpha$ \\
\hline \multirow[t]{2}{*}{23} & $1.23(s)$ & $0.89(s)$ & $3.71(d ; 9.9)$ & $3.69^{\mathrm{a}}$ & $1.25(s)$ & $1.28(s)$ \\
\hline & & & $4.18(d ; 10.3)$ & $4.29^{\mathrm{a}}$ & & \\
\hline 24 & $1.01(s)$ & $0.86(s)$ & $1.04(s)$ & $0.91(s)$ & $0.96(s)$ & $0.97(s)$ \\
\hline 25 & $0.87(s)$ & $0.81(s)$ & $0.95(s)$ & $0.95(s)$ & $0.90(s)$ & $0.88(s)$ \\
\hline 26 & $1.05(s)$ & $1.00(s)$ & $1.06(s)$ & $1.09(s)$ & $1.19(s)$ & $1.17(s)$ \\
\hline 27 & $1.22(s)$ & $1.22(s)$ & $1.16(s)$ & $1.67(s)$ & $1.69(s)$ & $1.69(s)$ \\
\hline 29 & $0.99(d ; 6.2) / \beta$ & $1.00(d ; 6.4) / \beta$ & $0.98(d ; 6.8)$ & $1.41(s)$ & $1.38(s)$ & $1.38(s)$ \\
\hline 30 & $0.94(d ; 5.9) / \alpha$ & $0.95(d ; 5.5) / \alpha$ & $0.92(d ; 6.1)$ & $1.10(d ; 5.8)$ & $1.05(d ; 6.5)$ & $1.05(d ; 6.3)$ \\
\hline 3 -acetoxy & -- & 2.05 & -- & -- & -- & -- \\
\hline Ara-1' & & & & $4.98(d ; 7.3)$ & $4.75(d ; 6.9)$ & $4.72(d ; 7.1)$ \\
\hline Ara-2' & & & & $4.42(t ; 7.6)$ & $4.44^{\mathrm{a}}$ & $4.57(t ; 8.3)$ \\
\hline Ara-3' & & & & $4.05(d d ; 8.8,3.4)$ & $4.16^{\mathrm{a}}$ & $4.21^{\mathrm{a}}$ \\
\hline Ara-4' & & & & $4.24^{\mathrm{a}}$ & $4.31^{\mathrm{a}}$ & $4.41^{\mathrm{a}}$ \\
\hline \multirow[t]{2}{*}{ Ara-5, } & & & & $3.71^{\text {a }} 4.27^{\mathrm{a}}$ & $3.81(d ; 10.6)$ & $3.72(d ; 11.6)$ \\
\hline & & & & & $4.31^{\mathrm{a}}$ & $4.18^{\mathrm{a}}$ \\
\hline Glc-1', & & & & & & $5.38(d ; 7.6)$ \\
\hline Glc-2' & & & & & & $4.01^{\mathrm{a}}$ \\
\hline Glc-3', & & & & & & $4.24^{\mathrm{a}}$ \\
\hline Glc-4', & & & & & & $4.22^{\mathrm{a}}$ \\
\hline Glc-5 & & & & & & $3.98^{\mathrm{a}}$ \\
\hline \multirow[t]{2}{*}{ Glc-6', } & & & & & & 4.37 a 4.53 \\
\hline & & & & & & $(d, 11.8)$ \\
\hline Glc-1" & & & & & $6.31(d ; 8.0)$ & $6.30(d ; 7.9)$ \\
\hline Glc-2” & & & & & $4.23^{\mathrm{a}}$ & $4.22^{\mathrm{a}}$ \\
\hline Glc-3” & & & & & $4.30^{\mathrm{a}}$ & $4.30(t ; 8.6)$ \\
\hline Glc-4" & & & & & $4.34^{\mathrm{a}}$ & $4.34^{\mathrm{a}}$ \\
\hline Glc-5” & & & & & $4.04^{\mathrm{a}}$ & $4.04^{\mathrm{a}}$ \\
\hline \multirow[t]{2}{*}{ Glc-6" } & & & & & $4.43^{\text {a }} 4.48$ & $4.38^{\text {a }} 4.47$ \\
\hline & & & & & $(d, 11.8)$ & $(d, 11.0)$ \\
\hline
\end{tabular}

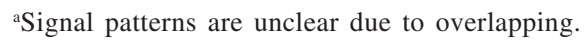


indicated the free carboxylic acid group, in accordance with the IR absorption at $1693 \mathrm{~cm}^{-1}$. Due to overlapping signals, the presence of an equatorial $\mathrm{CH}_{2} \mathrm{OH} \alpha-23$ in 4 could not be directly observed by the NOE enhancements related with the protons $3 \alpha$ and $5 \alpha$, but could be proven indirectly, considering the NOE enhancements detected between $\mathrm{CH}_{3} \beta-24(\delta 0,91)$ and $\mathrm{H} \beta-2(\delta 1.98)$. An important remark for the structure elucidation is the presence of the equatorial $\mathrm{CH}_{2} \mathrm{OH} \alpha-23$ group that is responsible for the $\gamma$-effect on C-5 ( $\delta 47.7)$, in contrast to compounds 1 and 2 with equatorial $\mathrm{CH}_{3} \alpha-23$, where $\mathrm{C}-5$ appears at $\delta 56( \pm 0.9$ ppm) and to the values reported for oleanolic acid, ${ }^{11}$ rotungenic acid ${ }^{12}$ and brevicuspisaponin $1 .{ }^{13}$ In addition, the strongest upfield shift of the neighboring $\mathrm{CH}_{3} \beta-24$ at $\delta 13.7$ displayed the same diagnostic value as observed for rotundic acid derivatives. ${ }^{14}$ Hence, compound $\mathbf{4}$ was found to be $3 \beta-O-\alpha$-L-arabinopyranosyl rotundic acid, a new saponin named here mateside.

Compound 5 was identified by $1 \mathrm{D}$ and $2 \mathrm{D}$ NMR spectroscopic data as ziyu-glycoside I $(3 \beta-O-\alpha-\mathrm{L}-$ arabinopyranosyl pomolic acid $28 \beta-O-\beta$-Dglucopyranosylester). This saponin was first reported for the roots of Sanguisorba officinalis (Rosaceae). ${ }^{15,16}$ It was also reported for other Ilex species: leaves of I. cornuta, ${ }^{17}$ fruits of $I$. crenata, ${ }^{18}$ leaves of $I$. kundincha,${ }^{19}$ and named in this last report as kundinoside $\mathrm{H}$. The FABMS, and the ${ }^{1} \mathrm{H} N M R,{ }^{13} \mathrm{C}$ NMR, DEPT, ${ }^{1} \mathrm{H}-{ }^{1} \mathrm{H}$ COSY, HMQC and HMBC experiments were performed to $\mathbf{5}$ and were in accordance with the reported data.

The chemical evidences and the NMR spectral data of $\mathbf{6}$ indicated the structure of the ilexoside II, formulated as $3 \beta$ - $O$ - $\beta$-D-glucopyranosyl- $(1 \rightarrow 3) \alpha$-L-arabinopyranosyl pomolic acid $28 \beta-O-\beta$-D-glucopyranosylester, saponin isolated from leaves of Ilex crenata. ${ }^{18}$ The same saponin has been found in the leaves of Ilex kudincha and named ilexkudinoside $\mathrm{E}^{20}$ and thereafter from the leaves of Randia formosa (Rubiaceae) ${ }^{21}$ and named randiasaponin III.

The bitterness is one of the important taste quality criteria for beverages as coffee, beers or tees, and it also plays a determinant factor on the flavor of Maté products. Previously, we have determined the threshold bitterness value $(\mathrm{BV})$ by a modified filter paper method, originally described by Jisaka et al. ${ }^{22}$ for the aqueous extract from $I$. paraguariensis leaves $(500 \mu \mathrm{g})$, I. brevicuspis leaves $(100 \mu \mathrm{g})$, I. theezans leaves $(200 \mu \mathrm{g})$, I. interregima leaves (200 $\mu \mathrm{g})$ and $I$. dumosa leaves $(300 \mu \mathrm{g})$, and for the isolated saponins from leaves of I. paraguariensis and other Ilex species (see Figure 1). ${ }^{23}$ In the present work, using the same methodology and the same reference compound (quinine sulphate), we evaluated the bitterness of the main saponins from fruits of $I$. paraguariensis, mateside (4) and ilexoside II (6). It is interesting to note that the aqueous extract of $I$. paraguariensis leaves was the least bitter of all these extracts and that its saponins showed also a high threshold value. Matesaponin 1 is at least one hundred less bitter than the pedunculoside, the main saponin isolated from $I$. taubertiana and Ilex theezans ${ }^{4}$ and the presence of the glucose at C-28 and free hydroxy groups at C-3, C-19 and $\mathrm{C}-23$ seems to be decisive to the rough bitterness. In the case of the matesaponins 1, 2 and 4, the rising of the bitterness followed the increase of sugar units at the C-3 or C-28.

In the examined cases, the presence of isolated hydroxyl groups in the aglycone is not sufficient to guarantee a high bitterness. In spite of the occurrence of hydroxylation at C-19 and C-23, in resemblance to pedunculoside, for which the lower threshold bitterness value was found, the saponin mateside presented a high

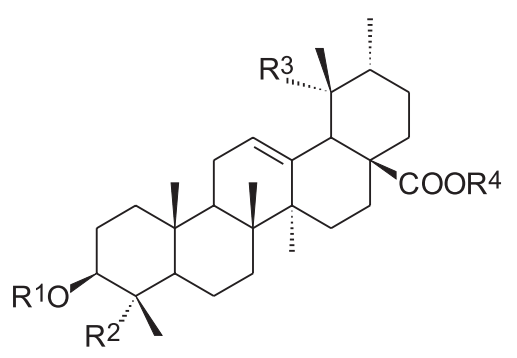

Matesaponin J3 $(>400 \mu \mathrm{g})$

Matesaponin $1(>400 \mu \mathrm{g})$

Matesaponin $2(200 \mu \mathrm{g})$

Matesaponin $4(100 \mu \mathrm{g})$

Mateside $(4 ;>400 \mu \mathrm{g})$

Ilexoside II $(6 ; 30 \mu \mathrm{g})$

Pedunculoside $(4 \mu \mathrm{g})$
R1

$\alpha-$ L-Rha1 $\rightarrow 2 \alpha-$ L-Ara $1 \rightarrow$

$\beta-\mathrm{D}-\mathrm{Glc}_{1} \rightarrow 3 \alpha-\mathrm{L}-\mathrm{Ara} 1 \rightarrow$

$\beta-\mathrm{D}-\mathrm{Glc}_{1} \rightarrow 3 \alpha-\mathrm{L}-\mathrm{Ara}_{2} \rightarrow$

$\alpha-L-R h a 1$

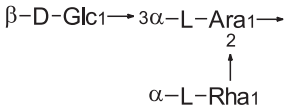

$\alpha-\mathrm{L}-\mathrm{Ara} 1 \rightarrow$

$\beta-\mathrm{D}-\mathrm{Glc} 1 \rightarrow 3 \alpha-\mathrm{L}-\mathrm{Ara} 1 \rightarrow$

$\mathrm{H}$

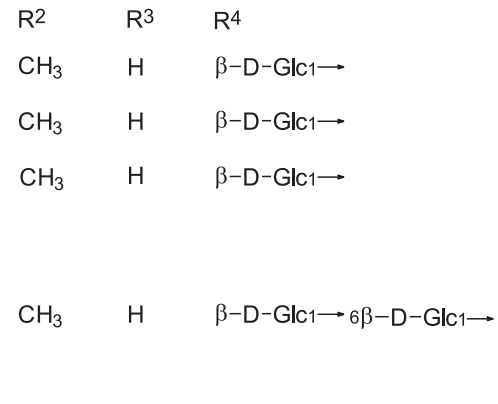

$\mathrm{CH}_{2} \mathrm{OH} \mathrm{OH} \quad \mathrm{H}$

$\mathrm{CH}_{3} \quad \mathrm{OH} \quad \beta-\mathrm{D}-\mathrm{Gl}_{1} \rightarrow$

$\mathrm{CH}_{2} \mathrm{OH} \quad \mathrm{OH} \quad \beta-\mathrm{D}-\mathrm{Glc}_{1} \rightarrow$

Figure 1. Threshold bitterness values for saponins from the leaves (matesaponin J3, matesaponins 1, 2 and 4) and fruits (mateside, ilexoside II) of Ilex paraguariensis and pedunculoside from the leaves of I. taubertiana and I. Theezans. 
$\mathrm{BV}$ of $>400 \mu \mathrm{g}$, which can be explained as arising from the lack of the glycosyl unit at C-28. In contrast, the presence of this glycosyl unit in ilexoside II, together with the hydroxylation at C-19 and C-23, and the occurrence of two sugar units at the $\mathrm{C}-3$, conferred to this saponin a high bitter taste with BV of $30 \mu \mathrm{g}$.

These results confirm the importance of the saponins for the taste of the beverages prepared from Maté and suggest that usage of the fruits will impart strong modification on the taste. At this time, there is no legal statements concerning the amount of fruit that can be allowed with the leaves and twigs to prepare the Maté product. If the plant material is collected in the period from December to February, a significant amount of fruits will be processed together. Considering that its saponins differ from those found in its leaves ${ }^{2,3}$ and considering the pronounced bitter taste of ilexoside II, one of the major saponins, the added amount of fruits can produce chemical variation on the final product that has unknown physiological and pharmacological consequences. Further biological investigation on the fruit of Ilex paraguariensis are required to clear this question.

\section{Experimental}

\section{Plant material}

Plants from three native populations from the States Rio Grande do Sul, Paraná, Paraná and Mato Grosso do Sul were numbered in situ for further studies in genetics, physiology, morphology, ecological and chemical analyses, as described previously. ${ }^{24}$ We analyzed a pooled sample from the fruits from these populations. A herbarium specimen (ICN-68648) is on deposit in the Herbarium of the Botany Department of the Federal university of Rio Grande do Sul.

\section{Extraction and isolation}

Fresh fruits $(10 \mathrm{Kg})$ were crushed and extracted with $\mathrm{EtOH} / \mathrm{H}_{2} \mathrm{O} 7: 3$ at room temperature (3 $\mathrm{x} 7$ days). The hydroethanolic extract was partially evaporated to eliminate the $\mathrm{EtOH}$, and extracted with $n$ - $\mathrm{BuOH}$. The organic phase was evaporated to dryness to give the saponins fraction $(150 \mathrm{~g})$. Part of this residue $(97 \mathrm{~g})$ was extracted with petrol/EtOAc $(1: 1,21)$ to give $12 \mathrm{~g}$ of a syrupy residue and with EtOAc $(1.5 \mathrm{l})$ to give $6.5 \mathrm{~g}$ of a green residue and with $\mathrm{MeOH}(1.51)$ to give $68 \mathrm{~g}$ of a yellow residue. Repeated chromatography of the EtOAc residue gave compound $\mathbf{1}$ (174 $\mathrm{mg}$ ) and pure compounds 2 (24 mg) and $3(4 \mathrm{mg})$, and of the $\mathrm{MeOH}$ residue gave compounds 4 (21 mg), 5 (6 mg) and 6 (36 mg). Pure compound 1 (15 mg) was obtained by crystallization from $t$-butyl methyl ether/EtOH 9:1.

\section{General procedures}

Melting points were obtained with a Kofler melting point apparatus and are uncorrected. IR spectra were recorded with a Perkin-Elmer 881 spectrophotometer. Optical rotations were measured on a Perkin-Elmer 241 polarimeter. EIMS spectra were performed on a MS 50 spectrometer and FABMS spectra on a VG ZAB HS spectrometer. ${ }^{1} \mathrm{H}$ and ${ }^{13} \mathrm{C}$ NMR spectra were recorded on Bruker AMX 500 spectrometer. TLC were carried out on silica gel (Merck) $\mathrm{GF}_{254}$, using eluents $\mathrm{CHCl}_{3} / \mathrm{MeOH}$ 98:2 for compounds 2, 95:5 for $\mathbf{1}$ and 9:1 for $\mathbf{3} ; \mathrm{CHCl}_{3} / \mathrm{EtOH} /$ $\mathrm{H}_{2} \mathrm{O}$ 90:40:5 for 4, 80:40:5 for 5 and 40:40:5 for $\mathbf{6}$ and EtOAc/MeOH/HOAc/ $\mathrm{H}_{2} \mathrm{O}$ 13:3:4:3 for the sugars. All compounds were visualized using the vanillin-sulfuric acid reagent $/ 100 \% / 10 \mathrm{~min}$. The opened $\mathrm{CC}$ were performed on a normal phase silica gel $40-60 \mathrm{~mm}$ using eluents $\mathrm{CHCl}_{3} /$ $\mathrm{MeOH}$ 98:2 $\rightarrow$ 9: 1 for compounds $\mathbf{1 ,} 2$ and 3; $\mathrm{CHCl}_{3} / \mathrm{EtOH} /$ $\mathrm{H}_{2} \mathrm{O} 100: 40: 5 \rightarrow 80: 40: 5$ for $\mathbf{4}$ and $\mathrm{CHCl}_{3} / \mathrm{EtOH} / \mathrm{H}_{2} \mathrm{O}$ 80:40:5 for 5 and 40:40:5 for 6; on phase LiChropep C-18, 40-63 mm using $\mathrm{MeOH} / \mathrm{H}_{2} \mathrm{O} 4: 1$ for $\mathbf{4}$ and 5, and 3:1 for 6; Sephadex LH-20 and MeOH as eluant were used to the purification of $\mathbf{4}$ and $\mathbf{5}$.

\section{Compound 1 (ursolic acid)}

White powder, mp 237-240 $;[\alpha]^{20}{ }_{589}+21.4^{\circ},[\alpha]^{20}{ }_{578}$ $+63.2^{\circ},[\alpha]^{20}{ }_{546}+72.3^{\circ},[\alpha]^{20}{ }_{436}+126.7^{\circ}$ and $[\alpha]^{20}{ }_{365}+114.9^{\circ}$ (MeOH, $c 0.4$ ); ${ }^{1} \mathrm{H}$ and ${ }^{13} \mathrm{C}$ NMR (see Tables 1 and 2); EIMS $m / z: 456.4[\mathrm{M}]^{+*}, 438.4,423.4,300.3,248.3,203.2$, 133.1; HRMS $m / z: 456.3603\left(\mathrm{C}_{30} \mathrm{H}_{48} \mathrm{O}_{3}\right)$.

\section{Compound 2 (acetylursolic acid)}

White powder, mp 181-183 $;[\alpha]^{20}{ }_{589}+60.3^{\circ},[\alpha]^{20}{ }_{578}$ $+63.5^{\circ},[\alpha]^{20}{ }_{546}+72.3^{\circ},[\alpha]^{20}{ }_{436}+123.6^{\circ}$ and $[\alpha]^{20}{ }_{365}+193.8^{\circ}$ $\left(\mathrm{CHCl}_{3}, c 0.5\right) ;{ }^{1} \mathrm{H}$ and ${ }^{13} \mathrm{C} \mathrm{NMR}$ (see Tables 1 and 2); EIMS $m / z: 498.4$ [M] $^{+\bullet}, 483.4,468.4,452.4,438.3,423.3,395.4$, 300.2, 248.2, 203.2, 190.2, 133.1; HRMS m/z: 498.3715 $\left(\mathrm{C}_{32} \mathrm{H}_{50} \mathrm{O}_{4}\right)$.

\section{Compound 3 (23-hydroxyursolic acid)}

White powder, mp 185-188 ; $[\alpha]^{20}{ }_{589}+40^{\circ},[\alpha]^{20}{ }_{578}+43^{\circ}$, $[\alpha]^{20}{ }_{546}+49^{\circ},[\alpha]^{20}{ }_{436}+87^{\circ}$ and $[\alpha]^{20}{ }_{365}+143^{\circ}(\mathrm{MeOH}, c$ 0.2); ${ }^{1} \mathrm{H}$ and ${ }^{13} \mathrm{C}$ NMR (see Tables 1 and 2); EIMS $m / z: 472.4$ $[\mathrm{M}]^{+}, 454.3,436.3,426.4,396.4,330.1,300.2,287.3$, 
248.2, 203.2, 175.2, 133.2; HRMS $m / z: 472.3556$ $\left(\mathrm{C}_{30} \mathrm{H}_{48} \mathrm{O}_{4}\right)$.

Compound 4 (Mateside: 3 $\beta$-O- $\alpha$-L-arabinopyranosyl rotundic acid)

White powder, mp $180-184^{\circ} ;[\alpha]^{20}{ }_{589}+25.8^{\circ},[\alpha]^{20}{ }_{578}$ $+27.8^{\circ},[\alpha]^{20}{ }_{546}+31.3^{\circ},[\alpha]^{20}{ }_{436}+52.3^{\circ}$ and $[\alpha]^{20}{ }_{365}+79.1^{\circ}$ (MeOH, $c$ 0.5); ${ }^{1} \mathrm{H}$ and ${ }^{13} \mathrm{C}$ NMR (see Tables 1 and 2); FABMS $m / z: 643.3[\mathrm{M}+\mathrm{Na}]^{+}, 597.3,439.1,355.2,307.1$, 289.0, 234.0.

Compound 5 (Ziyu-glycoside I: 3 $\beta$-O- $\alpha$-L-arabinopyranosyl pomolic acid 28 $\beta$-O- $\beta$-D-glucopyranosylester)

White powder, mp 198-202 ; $[\alpha]^{20}{ }_{589}+9^{\circ},[\alpha]^{20}{ }_{578}+13^{\circ}$, $[\alpha]^{20}{ }_{546}+12^{\circ},[\alpha]^{20}{ }_{436}+20^{\circ}$ and $[\alpha]^{20}{ }_{365}+30^{\circ}(\mathrm{MeOH}, c 0.1)$; ${ }^{1} \mathrm{H}$ and ${ }^{13} \mathrm{C}$ NMR (see Tables 1 and 2); FABMS $m / z: 789.4$ $[\mathrm{M}+\mathrm{Na}]^{+}, 689.3,671.2,468.1,453.3,409.2,329.0,307.0$.

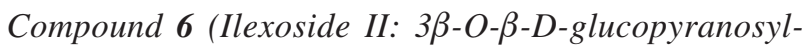
$(1 \rightarrow 3) \alpha$-L-arabinopyranosyl pomolic acid $28 \beta-O-\beta-D$ glucopyranosylester)

Crystals, mp 235-236 ; $[\alpha]^{20}{ }_{589}+7.5^{\circ},[\alpha]^{20}{ }_{578}+8.1^{\circ}$, $[\alpha]^{20}{ }_{546}+9.0^{\circ},[\alpha]_{436}^{20}+14.8^{\circ}$ and $[\alpha]_{365}^{20}+21.8^{\circ}(\mathrm{MeOH}, c$ 1.0); ${ }^{1} \mathrm{H}$ and ${ }^{13} \mathrm{C}$ NMR (see Tables 1 and 2); FABMS $m / z$ : $951.5[\mathrm{M}+\mathrm{Na}]^{+}, 789.3,743.4$.

\section{Bitterness experiment}

The bitter activities were determined by the threshold amount using a filter paper tasting method (threshold bitterness value). ${ }^{22,23}$ In our experiments, a known amount of a pure substance (in $\mu \mathrm{g}$ ) was used to impregnate a filter paper $\left(1 \mathrm{~cm}^{2}, 0.2 \mathrm{~mm}\right)$ and 15 volunteers tested increasing amounts. One hour before the experiment the participants should not eat or smoke, just were allowed to drink water. People that had to take medicine regularly and those who did not perceive the bitterness of quinine sulphate at $10 \mathrm{mg}$ were excluded. To avoid any influence of the slight taste of the filter paper in this organoleptical test, the experiment was initiated by giving a non impregnated filter paper to the applicants and asking them to remember its taste, and thereafter increasing amounts of substance were tested. The participants were asked after $5 \mathrm{sec}$. to assign the taste as "bitter", "perhaps bitter" or "not bitter". The answer "perhaps bitter" was classified as "bitter" when it was followed by a positive answer. The threshold value was considered the amount that tasted bitter to at least eight volunteers.

\section{Acknowledgment}

We are grateful to Geraldo C. Coelho (Universidade de Ijuí), Luis Carlos Tarasconi (FEPAGRO) and Dr. Helga Winge (Universidade Federal do Rio Grande do Sul), for locating and helping to collect the plant material, as well as to Dr. M. L. Athayde, for the initial preparation of the fruits extract, to Dr. G. Eckhardt for recording the HRMEI and FABMS data, and to Mrs. U. Dahmen, for laboratorial assistance. This work was supported by research fellowships from DAAD (Germany) and CNPq (Brazil).

\section{References}

1. Beltrão, L.; Hoeflisch, V. A.; Tarasconi, L. C.; Guaranha, J. M. R.; Estudo da Cadeia Produtiva da Erva-mate, Porto Alegre: Fepagro, 1998; IBGE, Instituto Brasileiro de Geografia e Estatística, Senso Agropecuário 2001, http:// www.sidra.ibge.gov.br, accessed in October, 2003.

2. Gosmann, G.; Schenkel, E. P. ; Seligmann, O.; J. Nat. Prod. 1989, 52, 1367; Schenkel, E. P.; Gosmann, G. ; Guillaume, D.; Taketa, A. T. C.; J. Nat. Prod. 1995, 58, 438; Kraemer K. H.; Taketa, A. T. C.; Schenkel, E. P.; Gosmann, G.; Guillaume, D.; Phytochemistry 1996, 42, 1119; Schenkel E. P.; Montanha, J. A.; Gosmann, G. In Saponins Used in Food and Agriculture; Waller, G. R.; Yamasaki, K., eds., Plenum Press: New York, 1999.

3. Martinet, A.; Ndjoko, K.; Terraux, C.; Marston, A.; Hostettmann, K.; Schutz, Y.; Phytochem. Anal. 2001, 12, 48.

4. Taketa, A. T. C.; Schenkel, E. P.; Acta Farm. Bonaerense 1994, 13, 159; Taketa, A. T. C.; Schenkel, E. P.; Rev. Bras. Farm. 1995, 76, 9; Athayde, M. L.; Gosmann, G.; Guillaume, D.; Schenkel, E. P.; Acta Farm. Bonaerense 1999, 18, 49; Taketa, A. T. C.; Gondorf, E.; Breitmaier, G.; Schenkel, E. P.; Rev. Bras. Cien. Farm. 2002, 38, 155.

5. Tkachev, A.V.; Denisov, A. Y.; Gatilov, Y. V.; Bagryanskaya, I. Y.; Shevtsov, S. A.; Rybalova, T. V.; Tetrahedron 1994, 50, 11459.

6. Reher, G.; Budesínký, M.; Phytochemistry 1992, 31, 3909.

7. Fujita, R.; Duan, H.; Takaishi, Y.; Phytochemistry 2000, 53, 715.

8. Souza, M. P.; Matos, M. E. O.; Machado, M. I. L.; Braz Filho, R.; Vencato, I.; Mascarenhas, Y. P.; Phytochemistry 1984, 23, 2589 .

9. Furuya, T.; Orihara, Y.; Hayashi, C.; Phytochemistry 1987, 26, 715 .

10. Yano, I.; Nishiizumi, C.; Yoshikawa, K.; Arihara, S.; Phytochemistry 1993, 32, 417.

11. Nagao, T.; Tanaka, R.; Okabe, H.; Chem. Pharm. Bull. 1991, $39,889$.

12. Nakatani, M.; Miyazaki, Y.; Iwashita, T.; Naoki, H.; Hase, T.; Phytochemistry 1989, 28, 1479. 
13. Taketa, A. T. C.; Schmittmann-Schlager, T.; Guillaume, D.; Gosmann, G.; Schenkel, E. P.; Phytochemistry 2000, 53, 901.

14. Amimoto, K.; Yoshikawa, K.; Arihara, S.; Phytochemistry 1993, 33, 1475.

15. Yosioka, I.; Sugawara, T.; Ohsuka, A.; Kitagawa, I.; Chem. Pharm. Bull. 1971, 19, 1700.

16. Cheng, D. L.; Cao, X. P.; Phytochemistry 1992, 31, 1317.

17. Wenjuan, Q.; Xiue, W.; Junjie, Z.; Fukuyama, Y.; Yamada, T.; Nakagawa, K.; Phytochemistry 1986, 25, 913.

18. Arihara, S.; Kakuno, T.; Yoshikawa, K.; Phytochemistry 1992, 31, 2809.

19. Wang, H. Q.; Ouyang, M. A.; Yang, C. R.; Chen, Z. L.; Phytochemistry 1996, 41, 871 .
20. Nishimura, K.; Miyase, T.; Noguchi, H.; J. Nat. Prod. 1999, $62,1128$.

21. Hostettmann, K.; Sahpaz, S.; Gupta, M. P.; Phytochemistry 2000, 54, 77.

22. Jisaka, M.; Ohigashi, H.; Takagaki, T.; Nozaki, H.; Tada, T.; Hirota, M.; Irie, R.; Huffman, M. A.; Nishida, T.; Kaji, M.; Koshimizu, K.; Tetrahedron 1992, 48, 625.

23. Taketa, C. S. C.; Taketa, A. T. C.; Schenkel, E. P.; Spitzer, V.; Lebensmittelchemie 1998, 52, 20.

24. Athayde, M. L.; Coelho, G. C.; Schenkel, E. P.; Phytochemistry 2000, 55, 853 .
Received: November 5, 2002 Published on the web: February 19, 2004 